\title{
KAJIAN PENERAPAN EDI DALAM PENGELOLAAN RANTAI PASOKAN DI INDUSTRI MANUFAKTUR
}

\author{
Ade Surya Budiman \\ Program Studi Teknik Komputer \\ AMIK BSI Jakarta \\ Jl. R.S. Fatmawati No.24 Pondok Labu, Jakarta Selatan \\ ade.aum@bsi.ac.id
}

\begin{abstract}
Abstrak
Industri manufaktur merupakan jenis industri yang bisa dikatakan mustahil bisa berjalan tanpa keberadaan dan kolaborasi dengan industri-industri manufaktur lainnya. Sebuah perusahaan manufaktur tidak bisa dikatakan berperan sebagai produsen atau sebagai konsumen saja, karena perusahaanperusahaan itu secara umum ikut berperan dalam kegiatan hulu hingga hilir dalam sistem manufaktur. Business to Business (B2B) adalah model perniagaan yang berlaku pada industri manufaktur. Perusahaan berkolaborasi membentuk rantai pasokan (supply chain) dan bersimbiosis untuk menjamin ketersediaan bahan baku dan ketersediaan pembeli dari hasil produksi mereka. Teknologi informasi dapat berperan penting dalam masalah pengelolaan informasi antar perusahaan dalam siklus rantai pasokan. Electronic Data Interchange (EDI) merupakan sebuah mekanisme pertukaran data secara elektronis antara pembeli dan penjual didalam sebuah siklus rantai pasokan. Didalam implementasinya, EDI diterjemahkan dalam beberapa model dan bentuk yang disesuaikan dengan kebutuhan perusahaan dan partner rantai pasokannya, sehingga perlu ditemukan formulasi yang standar mengenai bagaimana EDI diterapkan secara umum di industri manufaktur global. Didalam paper ini, akan dilakukan kajian mengenai bagaimana EDI berperan dalam pengelolaan rantai pasokan di industri manufaktur beserta model EDI yang telah diterapkan. Sehingga didapatkan gambaran mengenai standarisasi dari EDI dalam industri manufaktur.
\end{abstract}

Kata kunci :

Business to Business, Rantai Pasokan, Electronic Data Interchange, Industri Manufaktur

\begin{abstract}
Manufacturing industry is a kind of industry that can be said to be impossible to run without existence and collaboration with other manufacturing industries. A manufacturing company can not be said to play a role as a producer or as a consumer, as they generally play a role in upstream to downstream activities in the manufacturing system. Business to Business (B2B) is a commercial model applicable to the manufacturing industry. The company collaborates to form a supply chain and is symbiotic to ensure the availability of raw materials and the availability of buyers from their produce. Information technology can play an important role in the problem of information management between firms in the supply chain cycle. Electronic Data Interchange (EDI) is an electronic data exchange mechanism between buyers and sellers within a supply chain cycle. In its implementation, EDI is translated into several models and forms tailored to the needs of the company and its supply chain partners, so there is a need to find a standardized formulation of how EDI is generally applied in the global manufacturing industry. In this paper, a review of how EDI will play a role in supply chain management in the manufacturing industry and the EDI model that has been implemented. So we get a picture about the standardization of EDI in the manufacturing industry.
\end{abstract}

Keywords :

Business to Business, Supply chain, Electronic Data Interchange, Manufacturing Industry. 


\section{Pendahuluan}

\section{I.1 Latar Belakang}

Teknologi informasi menjadi bagian yang tidak bisa dipisahkan dari berbagai bidang dan aplikasi bisnis. E-commerce sebagai tulang punggung bisnis sejumlah pelaku dunia usaha, korporasi dan industri merupakan representasi masuknya teknologi informasi kedalam bidang perdagangan jasa dan barang.

Pesatnya perkembangan teknologi dibidang elektronika, telekomunikasi dan informasi semakin mempercepat pertumbuhan dan perkembangan ekonomi baik dunia usaha dinegara berkembang, lebih-lebih lagi dunia usaha di negara maju. Sejumlah rekayasa teknologi dikembangkan untuk makin memudahkan transaksi data, informasi hingga keuangan. Sistem Electronic Data Interchange (EDI) adalah model teknologi yang menggabungkan aspek elektronika, telekomunikasi dan informasi, yang dikembangkan untuk memudahkan proses transaksi dan pertukaran informasi dalam e-commerce terutama untuk model bisnis Business to Business (B2B).

B2B yang umumnya melibatkan pelaku usaha besar (korporasi) sangat membutuhkan peran teknologi untuk memudahkan setiap proses yang berjalan didalamnya. Hal ini dikarenakan B2B umumnya melibatkan jaringan usaha yang besar dan tidak mampu berdiri sendiri. Model bisnis B2B berkaitan erat dengan adanya supply and demand antar korporasi, yang biasa dijabarkan sebagai rantai pasokan (supply chain). Industri manufaktur yang merupakan contoh umum dari model bisnis B2B juga sangat bergantung dan sangat memperhatikan aspek rantai pasokan ini untuk menjamin keberlangsungan bisnis mereka.

Namun, di Indonesia khususnya, pengelolaan rantai pasokan (supply chain management) di bidang manufaktur belum banyak terbantu oleh perkembangan teknologi informasi. Sebagai contoh, belum maksimal dan efektifnya penggunaan teknologi EDI dalam proses bisnis korporasi pada umumnya.

\section{I.2 Permasalahan}

Pentingnya teknologi informasi dalam pertukaran data dan informasi akan sangat memudahkan pelaksanaan pengelolaan rantai pasokan antar korporasi. EDI menjadi komponen utama dalam penerapan teknologi informasi bagi $\mathrm{B} 2 \mathrm{~B}$ e-commerce yang terintegrasi dalam sebuah sistem rantai pasokan.
Namun, perlu ditegaskan kembali bagaimana penerapan EDI dalam industri manufaktur dalam kaitannya dengan teknologi informasi. Sehingga dibutuhkan analisis untuk menentukan titik temu yang terbaik untuk menyatukan dua tema yang sangat berkaitan tersebut.

Didalam penelitian ini penulis merangkaikan keterkaitan antara supply chain management dengan e-commerce melalui penggunaan teknologi EDI.

\section{KAJIAN LITERATUR}

\section{II.1 Penelitian Terkait}

Conan C. Albrecht dan kawan-kawan (Albrecht, Dean \& Hansen, 2003), mengetengahkan sebuah penelitian yang bertujuan untuk mendefinisikan standar keberhasilan dari suatu arsitektur Electronic Commerce. Para peneliti membandingkan serangkaian jenis arsitektur dalam Electronic Commerce, diantaranya Electronic Data Interchange, company website, B2B hubs, e-Procurement system dan layanan web. Dari penelitian ini ditemukan titik kegagalan atau kelemahan dari masing-masing arsitektur serta keunggulan dari arsitektur Electronic Commerce yang diteliti.

Dalam penelitian lainnya (Philip, Oluwatolani \& Joshua, 2011), dibahas mengenai keamanan dalam penggunaan Electronic Data Interchange, serta bagaimana mengurangi intervensi manusia dalam proses transfer data antar perusahaan yang berkolaborasi dalam Electronic Data Interchange tersebut. Dari penelitian ini diperoleh overview dari permasalahan dalam Electronic Data Interchange serta standar-standar umum implementasi Electronic Data Interchange, termasuk sistem keamanan yang direkomendasikan.

\section{II.2 Supply chain Management}

Pengelolaan rantai pasokan (supply chain management/SCM) memiliki beberapa definisi, diantaranya:

1. SCM adalah pengelolaan suatu jaringan bisnis yang saling berhubungan yang terlibat dalam penyediaan akhir dari paket produk dan layanan yang diperlukan oleh konsumen akhir (Harland, 1996).

2. SCM meliputi perencanaan dan pengelolaan semua kegiatan yang terlibat dalam pengadaan sumber daya, konversi pengadaan, dan manajemen logistik. Ini juga mencakup komponen penting koordinasi dan kolaborasi dengan mitra sejenis, yang bisa berupa pemasok, perantara, penyedia 
layanan pihak ketiga, dan pelanggan. Pada intinya, manajemen rantai suplai mengintegrasikan pasokan dan manajemen permintaan secara internal perusahaan maupun lintas/antar perusahaan (Council of Supply Chain Management Professionals, 2017).

Masih banyak lagi definisi dari SCM tersebut dari berbagai pandangan dan pendapat. Namun, secara garis besar SCM adalah rangkaian proses yang menghubungkan mulai dari produsen hingga konsumen.

Dengan kata lain, SCM merupakan suatu sistem yang terintegrasi dalam sebuah jejaring bisnis yang saling berkaitan, saling membutuhkan dan saling bergantung satu sama lain. SCM melibatkan hubungan vertikal (upstream dan downstream) maupun hubungan horizontal antar perusahaan atau industri yang terlibat dalam jejaring tersebut.

SCM tidak hanya berbicara tentang produk barang ataupun jasa, namun SCM juga terkait dengan pengelolaan data yaitu pertukaran data antar perusahaan yang berelasi dalam sebuah rantai pasokan.

Dalam rantai bisnis B2B yang diperlihatkan didalam Gambar 1 supply chain management menghubungkan pembeli dan supplier dengan melibatkan jaringan transportasi dan telekomunikasi yang terintegrasi untuk menghubungkan pemesanan, pembelian dan penjualan serta logistik yang terlibat.

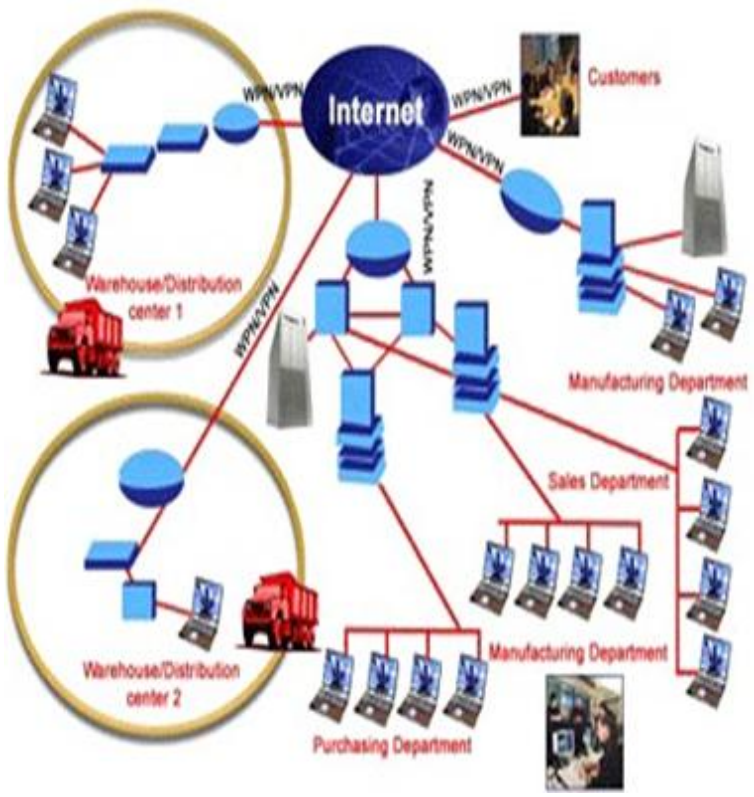

Gambar 1. Supply Chain Management

\section{II.3 Electronic Data Interchange.}

Proses pertukaran data dan informasi berbentuk elektronis yang kemudian juga menggunakan media elektronis, dapat didefinisikan sebagai pertukaran data secara elektronis (Electronic Data Interchange/EDI). Secara teknis, EDI merupakan pertukaran data bisnis antar komputer yang bersifat rutin diantara sesama rekan/partner dagang dengan menggunakan format data standar.

Konsep utama dari EDI adalah:

1. Dari Komputer ke Komputer.

Dilihat dari segi efisiensi, EDI mestinya langsung menghubungkan komputer pengirim dengan komputer penerima tanpa adanya keterlibatan manusia didalamnya. Walaupun kondisi efisien ini tidak selalu bisa dicapai.

2. Data Bisnis yang bersifat rutin.

Antara pemasok dan konsumen selalu ada datadata yang besifat rutin seperti misalnya purchase order dan invoice. EDI bisa melakukan transmisi data jenis ini, tanpa perlu intervensi manusia dalam prosesnya. EDI tidak efektif bila harus memproses data bisnis yang bersifat rutin, seperti misal kontrak kerja atau informasi yang menghendaki intervensi manusia untuk membaca dan menganalisisnya.

3. Format Data Standar

Bentuk dokumen data yang ditansmisikan juga harus distandarisasi. EDI tidak akan mampu mengolah dan mentransmisikan teks dokumen yang tidak terstruktur.

Perbandingan kerja antara model konvensional dengan model EDI digambarkan pada gambar 2. Dari gambar tersebut dapat dideskripsikan perrbandingan antara proses konvensional dengan proses EDI adalah dari segi efisiensi waktu dan tenaga kerja.

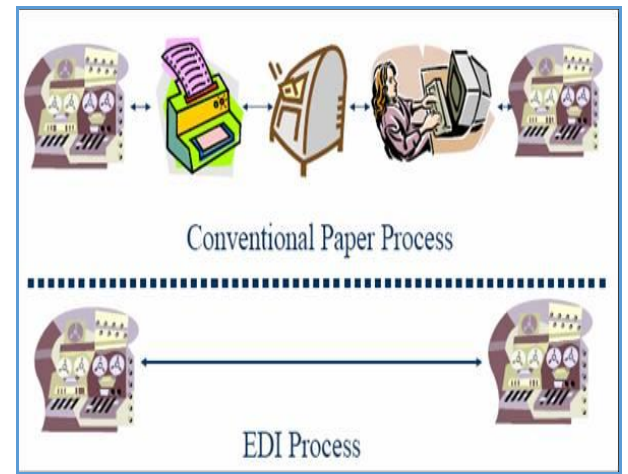

Gambar 2. Proses Konvensional versus Proses EDI 
Pada model konvensional, antara komputer pemasok dan konsumen terdapat beberapa perangkat dan intervensi manusia yang dibutuhkan agar data diantara pelaku bisnis tersebut bisa dipertukarkan.

Diantara proses yang paling utama tersebut adalah pembuatan dokumen, pencetakan dokumen atau pengiriman dokumen via faximile atau e-mail yang kesemuanya membutuhkan intervensi manusia dalam kegiatan tersebut.

Sebaliknya, pada model EDI intervensi manusia sama sekali tidak dibutuhkan. Hal ini bisa diberlakukan selama ada sinkronisasi dan penyeragaman/standarisasi format dokumen data yang ingin ditansmisikan. Dengan demikian konsep humanless dan paperless bisa diberlakukan pada model EDI ini.

Dengan spesifikasi teknis yang dimiliki oleh teknologi ini, model EDI memiliki banyak manfaat dibandingan dengan model konvensional dalam proses bisnis. Secara teori ada 4 keuntungan utama dari EDI, yaitu:

1. Kecepatan.

Dengan integrasi dan sinkronisasi antar komputer secara langsung, proses pertukaran data akan lebih cepat serta dengan waktu tunda yang hampir tidak ada.

2. Akurasi.

Melalui konsep "tanpa pengetikan ulang" maka EDI mengurangi kemungkinan kesalahan dalam pembuatan dokumen. EDI menggunakan dokumen data yang sudah ada, kemudian mengirimnya kembali tanpa harus dibuat ulang. Memasukkan data baru berpotensi kesalahan sebesar 0,5 \% - 3 $\%$ pada dokumen. Dengan sendirinya, pada jumlah transaksi yang besar, potensi kesalahan juga akan semakin membesar.

3. Penyederhanaan.

EDI menstandarisasi format dokumen dari data yang akan dipertukarkan serta EDI akan mengelola dokumen-dokumen yang dikirim dan diterima secara otomatis, sehingga lebih mudah diketemukan dan dipergunakan apabila dibutuhkan.

4. Keamanan.

Dengan sistem/mode transmisi yang hanya bisa diakses oleh pihak yang memiliki dan diberikan otoritas khusus, maka data-data EDI tidak bisa dengan mudah diakses dan dimodifikasi oleh sembarangan orang sebagaimana akses terhadap data yang dikirm melalui surat konvensional atau surat elektronik. Dokumen EDI juga kurang rentan terhadap isu-isu keamanan data elektronik seperti misalnya virus.

Dalam dunia industri, khususnya industri manufaktur, hal diatas akan menghasilkan beberapa hal berikut:

1. Siklus waktu pemesanan dan pembelian akan lebih cepat

2. Aliran dana yang lebih cepat

3. Mengurangi inventaris perangkat dan tenaga kerja

4. Mampu menghantarkan proses manufakturing yang tepat pada waktunya

5. Meningkatkan hubungan dagang antar pelaku bisnis.

\section{II.4 Beberapa Implementasi dalam Industri Manufaktur Global}

Meskipun belum diterapkan secara luas di Indonesia, namun telah cukup banyak industri manufaktur internasional yang memanfaatkan EDI dalam pengelolaan rantai pasokan mereka. Diantaranya adalah (OpenText Business Network SA, 2015):

1. ArcelorMittal.

Perusahaan multinasional yang berbasis di Luxemburg ini bergerak dalam bidang pertambangan dan produsen baja. Sebagai salah satu produsen baja terbesar di dunia (menghasilkan sekitar $6 \%$ produk baja dunia), ArcelorMittal memiliki sejumlah tantangan terkait integrasi dan ekspansi bisnis perusahaan. Tantangan tersebut adalah: (i) Memfasilitasi dan mempercepat proses penambahan konsumen baru kedalam jaringan e-commerce $\mathrm{B} 2 \mathrm{~B}$ perusahaan; (ii) Migrasi sistem dari model koneksi individual point-to-point dengan masing-masing perusahaan rekanan, menuju model jaringan tunggal B2B untuk seluruh perusahaan rekanan; serta (iii) Mengurangi biaya pemeliharaan dan dukungan terhadap aplikasi B2B berbasis mainframe yang telah dibuat dan dipakai oleh masing-masing perusahaan yang terlibat selama ini.

Untuk mengatasi tantangan-tantangan bisnisnya, perusahaan ini melakukan perubahan sistem dan prosedural kedalam jaringan EDI. Jaringan EDI yang dikelola secara alih daya telah berhasil meningkatkan efektifitas dan efisiensi lalu lintas dokumen bisnis antar perusahaan rekanan ArcelorMittal. Model aplikasi B2B yang dibangun secara personal oleh masing-masing perusahaan yang terlibat (in-house B2B Application) diintegrasikan kedalam satu jaringan B2B (seamless B2B Network). Hal ini juga 
meningkatkan visibilitas bisnis dan identitas perusahaan secara global serta mempermudah setiap perusahaan dan rekanan perusahaan yang terlibat dalam mengawasi dan mengendalikan bisnis proses dan dokumen-dokumen yang berjalan dalam jaringan EDI.

2. Plastipak.

Bisnis inti perusahaan ini adalah dalam disain dan produksi kontainer plastik keras dan pengepakan untuk produk makanan, minuman ringan dan produk-produk konsumen lainnya.

Perusahaan ini berbasis di Amerika Serikat dan memperluas lokasinya hingga Eropa dan Brazil.

Plastipak memiliki tantangan terkait dengan: (i) Pengelolaan pertumbuhan global yang bersandar pada teknologi informasi yang dibangun secara inhouse, cenderung mudah bermasalah atau sering mengalami permasalahan; (ii) Menjaga kecepatan pertumbuhan secara eksponensial dengan adanya transaksi berbasis EDI.

Setelah sepenuhnya terintegrasi dengan sistem jaringan EDI yang dikelola dengan model alih daya kepada salah satu provider sistem EDI, Plastipak kemudian bisa mengurangi kesalahan dalam transaksi sehingga mencapai tingkat akurasi $97 \%$, peningkatan kemudahan pengawasan (visibility) terhadap siklus dokumen, serta pertumbuhan perusahaan yang baik tanpa memperbanyak jumlah karyawan full time (FTE).

3. BRF.

Perusahaan produsen makanan yang terdaftar dalam 100 perusahaan inovatif menurut Forbes pada tahun 2012 dan 2013 ini, memproduksi makanan yang tersebar di lima benua.

Perusahaan yang berbasis di Brazil dan memiliki perusahaan rekanan di 150 negara dengan beragam bahasa diantara perusahaan-perusahaan tersebut. Hal ini menyebabkan terjadinya beragam model dokumen, konektivitas dan regulasi perdagangan.

Tantangan bisnis yang dihadapi BRF adalah: (i) Kurangnya teknologi dan keahlian untuk efisiensi dalam hal kolaborasi antar perusahaan; dan (ii) tantangan yang bersumber dari adanya perusahaan rekanan yang berasal dari banyak negara disertai bahasa yang berbeda-beda, mempersulit dalam koordinasi antar tim dan perusahaan rekanan.

Penerapan EDI menghasilkan bisnis yang memiliki kehandalan perangkat dan keahlian dalam memperbaiki pertukaran informasi secara real time dan memperbaiki kolaborasi, disamping itu dengan adanya EDI bisa menjembatani perbedaan bahasa antar perusahaan rekanan BRF, serta terbentuknya integrasi antar perusahaan yang bermanfaat untuk meningkatkan tingkat layanan, meningkatkan profesionalitas BRF dan perusahaan rekanannya.

\section{II.5 Dokumen/Pesan yang Digunakan dalam EDI}

Teknologi dokumen atau pesan yang digunakan dalam EDI tentunya berbeda dengan format dan teknologi yang digunakan pada pertukaran data atau dokumen secara konvensional.

Format data yang populer untuk pengiriman data dalam EDI adalah yang dibuat oleh The American National Standards Institute (ANSI), yaitu ANSI X12 atau biasa disebut juga ASC X12. ASC sendiri adalah singkatan dari Accredited Standards Committee. Terdapat juga format lainnya seperti EDIFACT (The Electronic Data Interchange for Administration, Commerce and Transport). EDIFACT kebanyakan dipergunakan diluar Amerika Serikat. Sementara itu, di Amerika Serikat kebanyakan menggunakan ANSI $\mathrm{X} 12$ atau disebut juga X12.

Format dan teknologi dokumen atau pesan pada EDI, digambarkan pada gambar 3.

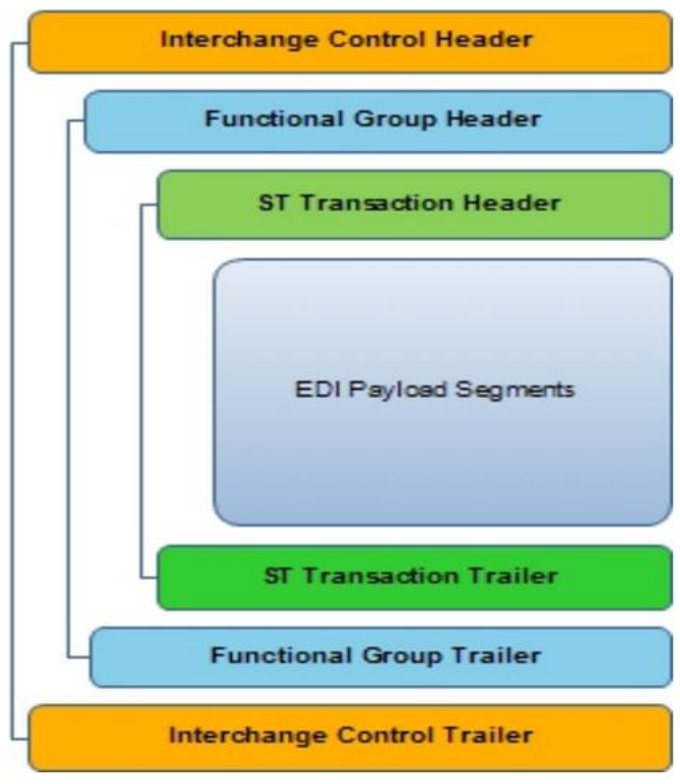

Gambar 3. Struktur File X12 EDI

Ada beberapa istilah yang ditemukan dalam EDI Message yang secara garis besar membagi proses pertukaran informasi kedalam beberapa langkah standarisasiyang harus dilakukan sebelum sesi 
pertukaran informasi (communication session) dimulai.

\section{Transaction Set}

Merupakan proses pembuatan format pesan atau informasi yang harus bisa dimengerti oleh penerima nantinya. Proses ini utamanya adalah pembentukan header, detail dan summary dari informasi yang dikirimkan. Terdiri atas dua komponen yaitu penanda awal rangkaian/set dokumen (ST Transaction Set Header) dan penanda akhir dari rangkaian/set dokumen (SE Transaction Set Trailler)

2. Function Group

Merupakan proses selanjutnya yang bertujuan membuat set dokumen kedalam bentuk file yang distandarisasi untuk EDI. Terdiri atas set fungsi yaitu awal dari grup fungsi (GS Functional Group Header) yang berisikan identifikasi grup, alamat pengirim dan penerima, versi dari standar yang digunakan dan jenis grup yang digunakan. Sementara set fungsi berikutnya adalah akhir dari grup fungsi (GE Functional Group Trailler) tersebut.

3. Interchange Envelope

Merupakan proses dimana entitas standar EDI ditransmisikan antar komputer yang berkomunikasi dalam sebuah transmisi tunggal. Terdiri atas komponen penanda awal transmisi (ISA Interchange Control Header) yang berisikan pengidentifikasi pertukaran (interchange), data pengirim dan penerima dan komponen-komponen data yang diperlukan untuk menginterpretasikan kedatangan data yang akan dipertukarkan. Komponen yang lain adalah penanda akhir transmisi (IEA Interchange Control Trailler).

4. Communication Session

Merupakan akhir dan inti dari proses pertukaran data, dimana komputer pengirim dan penerima mengkoordinasikan proses pertukaran atau komunikasi data. Terdiri atas dua Communication Transport Protocol yang merupakan metode dimana kedua komputer (pengirim dan penerima) mengkoordinasikan komunikasi dan pertukaran data diantara keduanya.

Gambaran lengkap komponen yang terdapat didalam transaksi EDI pada format data X12 diperlihatkan didalam gambar 5 .

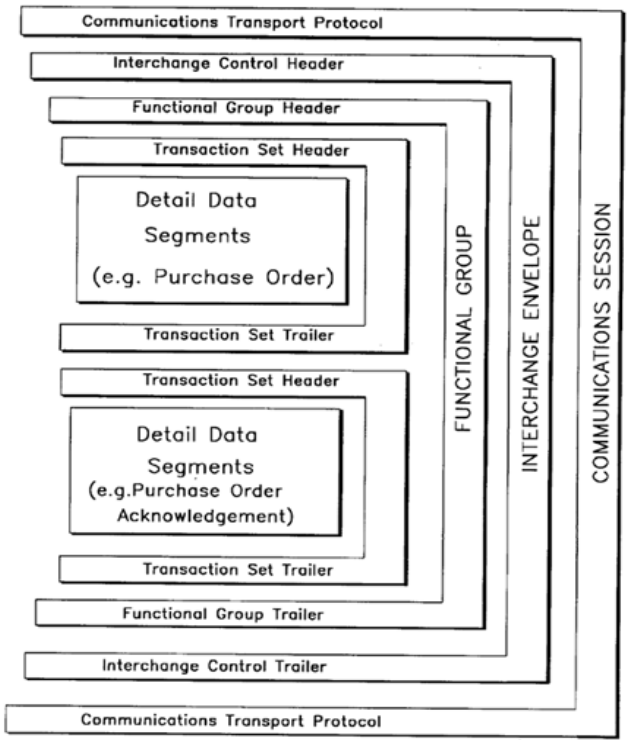

Gambar 4. Format Data X12

Secara singkat, Interchange Header (ISA) atau message envelope, berisikan sebuah Functional Groups (GS) yang berisi sebuah Transaction Header (ST) segment. Kebanyakan format data menggunakan konsep data segment dan data element untuk mengirim data.

Berikut ini adalah contoh langkah-langkah komunikasi dalam EDI (RDP Crystal, 2015).

1. Jika perusahaan $\mathrm{A}$ ingin mengirim sebuah alamat menuju perusahaan $\mathrm{B}$, alamat tersebut dapat dikirmkan melalui segmen N3 dan N4.

N3*112 ROAD WAY

$\mathrm{N} 4 *$ New York*NY*1114

2. Tidak ada yang sangat khusus mengenai data segment. Data segment biasanya terdiri atas 2-3 karakter. Beberapa diantaranya sebenarnya singkatan untuk isi data itu sendiri. Sebagai contoh, data segment NM1 berisi sebuah nama: $\mathrm{NM} 1 * \mathrm{IL} * 1 * \mathrm{John} *$ Smith $*$

3. Setelah Perusahaan A memiliki semua data yang dibutuhkan untuk dikirim ke Perusahaan B, maka perlu ditambahkan segmen tingkat atas (top level segment), atau amplop (envelope), untuk menandakan awal dari data. Dalam X12 bagian data segment itu disebut sebagai Interchange Header atau data segment ISA. Jenis segment ini disebut sebagai segment kendali (control segment).

ISA $* 00 * * 00 * \quad * \mathrm{ZZ} * \mathrm{SMITH} \quad * \mathrm{ZZ} * \mathrm{BCBSGA}$ *07011A*1350*U*00401*00000011*1*P*> 
EDI Message secara lengkap adalah seperti yang diperlihatkan didalam gambar 5 .

ISA*00**00**ZZ*SMITH *ZZ*BCBSGA*07011A*1350*U*00401*000000011*1*P*>
GS*HC*SMITH*BCBSGA*20070118*1350*11**0004010X098A1
ST*837*000000001
NM1*IL*1*John*Smith*
N3*112 ROAD WAY
N4*New York*NY*1114
SE*5*000000001
GE*1*11
IEA*1*000000011

Gambar 5. Contoh EDI Message

\section{Analisa dan Pembahasan}

\section{III.1 Manfaat dan Dukungan Sistem}

Sebagaimana telah disebutkan di awal tulisan, industri manufaktur adalah representasi dari sebuah relasi yang bersifat simbiosis mutualisme. Membentuk rantai pasokan yang tidak boleh putus untuk menjamin keberlangsungan produksi dan kegiatan bisnis baik berupa barang maupun jasa.

Pengelolaan rantai pasokan (SCM) membutuhkan koordinasi yang sangat baik antara pemasok dan pengguna, karena ketika SCM tidak berjalan dengan semestinya kegiatan produksi dalam industri manufaktur bisa tidak terkendali dan gagal memenuhi target produksi.

Dalam industri manufaktur, pemenuhan kebutuhan bahan baku tidak hanya sebatas yang dibutuhkan untuk bahan siap produksi (on-going production) saja, tetapi juga harus dipenuhi juga cadangan bahan baku yang cukup untuk proses produksi berikutnya kapanpun dibutuhkan. Hal ini untuk mengantisipasi kemungkinan kegagalan produk saat produksi maupun ketika meningkatnya permintaan hasil produk.

Lazimnya dalam proses pembelian pada B2B commerce, pemesanan, penagihan (invoice), pembelian (purchase order) hingga pengantaran (delivery order) adalah empat proses pertukaran dokumen yang sangat rutin dilakukan dan dikeluarkan.

Keempat proses ini tidak hanya menyangkut bahan baku produksi saja, namun juga menyangkut barang-barang penunjang produksi mulai dari perkakas perbaikan mesin/komponen pabrik hingga penyedian alat tulis kantor.

Industri manufaktur pada umumnya masih menggunakan cara konvensional dalam melakukan tiga proses rutin diatas. Beberapa kegiatan yang dilakukan dalam cara konvensional adalah sebagai berikut:

1. Pemeriksaan ketersediaan barang dan bahan baku produksi secara manual oleh perusahaan yang bersangkutan.

2. Perencanaan cadangan bahan baku secara manual oleh perusahaan yang bersangkutan.

3. Untuk melakukan pemesanan, dibuat semacam dokumen pemesanan barang dan pembelian barang (purchase order) yang dibuat secara manual kemudian dikirim melalui fax atau email.

4. Perusahaan penjual akan melakukan pengecekan manual kemudian menyatakan kesanggupan untuk menyediaakan barang yang diminta serta dilanjutkan dengan pengiriman invoice kepada pembeli.

5. Setelah atau sebelum uang dikirimkan dari pembeli kepada penjual, akan dikeluarkan delivery order oleh pihak penjual sebagai perintah dan bukti dalam pengiriman barang yang diminta.

Dari seluruh kegiatan tersebut, EDI bisa diterapkan mulai dari kegiatan ketiga hingga kelima. EDI memungkinkan perusahaan pemasok menerima order dari perusahaan konsumen terkait jumlah pembelian yang dibutuhkan hingga waktu pengiriman yang diiinginkan. EDI bisa dipergunakan dalam transaksi pembeli dan penjual sejak dilakukan pemesanan hingga pengantaran produk (delivery).

Namun dalam cara konvensional, hal yang perlu digarisbawahi adalah fakta bahwa hampir semua dokumen yang disebutkan dalam kegiatan rutin diatas adalah dokumen yang juga bersifat rutin dan masih dilakukan secara manual.

Hal ini akan berimbas pada efisiensi dan efektifitas kerja serta keuangan perusahaan. Karena, dokumen yang dibuat secara manual rentan terjadi kesalahan isi pada saat entry data, membtuhkan tenaga kerja dan perangkat yang lebih banyak, tidak paperless dan membutuhkan waktu yang lebih banyak untuk pengecekan secara manual dan juga lebih lama dalam proses pertukaran informasinya.

Dokumen-dokumen tersebut juga tidak bisa langsung ditindaklanjuti jika pekerja pada bagian yang terkait tidak memeriksa dan mengambil tindakan yang diperlukan secepatnya. Hal ini bisa saja terjadi, karena proses pengecekan ketersediaan bahan yang diminta juga membutuhkan waktu yang lama.

Efisiensi waktu dan efektifitas kerja menjadi hal yang sangat penting dalam proses produksi dalam industri manufaktur. Proses penyediaan dan pembelian bahan baku juga merupakan bagian inti 
dari proses produksi secara keseluruhan, sehingga kehilangan banyak waktu dan dana untuk proses tersebut bukanlah hal yang boleh terjadi.

Pembuatan dokumen secara manual, pengiriman dokumen hingga ke tindak lanjut dokumen adalah hal paling banyak memakan waktu. Sehingga lebih jauh, hal ini berdampak kepada proses produksi secara keseluruhan.

EDI dirancang untuk menutupi dan mangatasi masalah efisiensi waktu dan efektifitas kerja yang mungkin tejadi dalam bagian proses produksi yang berkaitan dengan pertukaran data antar perusahaan partner bisnis (pemasok dan konsumen).

Seringkali proses produksi terhambat karena tidak terjembataninya komunikasi dan pertukaran data yang menyangkut proses produksi seperti misalnya ketersediaan bahan baku antara perusahaan pemasok bahan baku dan perusahaan pengguna bahan baku.

Inti dari masalah ini sebenarnya tidak terlalu kompleks, yaitu hanya menyangkut sinkronisasi data antar perusahaan. Ketika sinkronisasi bisa dibuat, maka masalah efisiensi waktu dan efektifitas kerja tadi bisa diatasi dengan lebih baik.

Dengan standarisasi format informasi/pesan dari data-data yang dipertukarkan antar perusahaan oleh EDI, maka sinkronisasi data antar perusahaan tersebut bisa dibuat. Sinkronisasi yang dimaksud - yang terpenting - adalah kondisi data yang sifatnya real time.

Dengan demikian kondisi data pada sebuah perusahaan yang relevan dengan informasi data yang dimiliki oleh perusahaan partner kerja akan bisa disamakan. Dengan kata lain, perubahaan data pada sebuah perusahaan juga mengakibatkan perubahan data pada perusahaan partnernya secara real time.

Sebagai contoh, ketika sebuah perusahaan membutuhkan pasokan bahan baku baru sebagai cadangan bagi bahan baku yang mulai menipis, maka perusahaan pemasok bahan baku akan langsung mengetahui kondisi bahan baku di perusahaan konsumennya karena adanya sinkronisasi informasi dan format data standar.

Dengan demikian, kemungkinan ketidaktersediaan pasokan bahan baku bisa dihindari. Ketika kondisi kebutuhan bahan baku sudah diketahui secara real time, maka proses pemesanan, pembelian hingga pengantaran akan bisa dilakukan secara otomatis, tanpa melibatkan banyak campur tangan manusia (human intervention) dalam pengurusan semua data dan dokumennya.
Dengan demikian, peran EDI dalam industri manufaktur bisa menjadi sangat penting dalam kaitannya untuk meningkatkan efisiensi waktu dan efektifitas kerja dari proses produksi secara keseluruhan. Dengan sendirinya konsep SCM akan bisa diterapkan dengan lebih efektif dalam industri manufaktur khususnya dan B2B e-commerce pada umumnya.

\section{III.2 Review Dokumen EDI}

Dalam penelitian ini, penulis mengambil review terkait dengan salah satu dokumen rutin dan pada umumnya saat ini masih bersifat manual, yaitu dokumen Pemesanan Pembelian (Purchase Order).

Purchase Order (PO) merupakan dokumen yang mengikat pembeli dan penjual, dengan rincian terkait kesepakatan pembeli membeli sejumlah produk beserta ketetapan harganya, waktu pengantaran dan ketentuan mekanisme pembayarannya (Kokemuller, 2017).

Tahapan umum proses terkait Purchase Order adalah (Kokemuller, 2017):

1. Pengajuan (Submission)

Dalam proses ini, PO disiapkan oleh pembeli (biasanya bagian pembelian/purchasing department). PO berisikan nomor PO, tanggal pengiriman, alamat penagihan, alamat pengiriman, produk yang dibeli, beserta kuantitas dan harga produk.

2. Pemrosesan Pesanan (Order Processing)

Ketika pembeli mengajukan pembelian, berdasarkan dokumen yang diterima, penjual mempersiapkan produk yang akan dibeli. Penjual melakukan pemeriksaan ketersediaan produk yang diinginkan pembeli dari sistem inventory atau sistem gudang. Apabila produk tersedia, penjual mempersiapkan proses pengiriman dan memastikan akurasi pembayaran sesuai nomor PO dan rekening penjual.

3. Penyelesaian Pemasok (Supplier Use)

Penjual mempergunakan PO untuk pemenuhan pesanan dan proses pembayaran. Setelah produk dikeluarkan dari sistem inventory penjual, faktur penjualan (invoice) dipersiapkan berdasarkan produk yang dipesan untuk selanjutnya dipersiapkan proses pengirimannya. Ketika produk dikirimkan, penjual melakukan update pada sistem inventory mereka. Selanjutnya PO akan ditandai untuk menunggu proses pembayaran dari pembeli sesuai dengan kesepakatan cara dan waktu pembayaran. 
Dalam Gambar 6, diperlihatkan contoh dokumen pemesanan pembelian (Purchase Order) dalam bentuk manual.

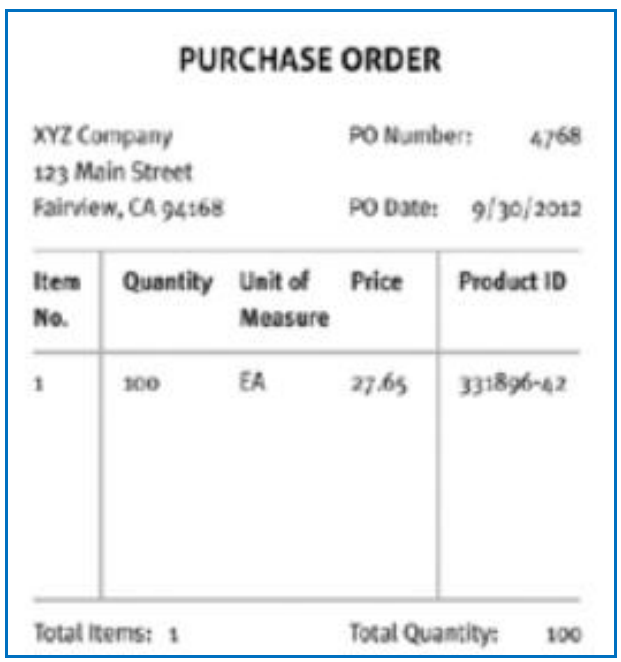

Gambar 6. Purchase Order Konvensional

Secara umum isi dari dokumen non EDI dan dokumen EDI mengandung komponen data yang sama. Sebagai contoh, sebuah dokumen Purchase Order (PO) akan selalu berisikan nama perusahaan, kontak perusahaan, produk yang akan dibeli, kuantitas dan sebagainya.

Dokumen EDI memiliki beragam format, diantaranya ANSI, EANCOM, EDIFACT, SAP dan HIPAA. Dalam penelitian ini diperlihatkan dua diantaranya yaitu ANSI dan EDIFACT.

ANSI awalnya dipergunakan oleh perusahaanperusahaan lintas sektor industri di wilayah amerika utara, akan tetapi saat ini lebih dari 300 ribu perusahaan di seluruh dunia telah mempergunakan standar ANSI X12 dalam transaksi bisnis sehari-hari (OpenText Business Network SA, 2015). Gambar 7 memperlihatkan bentuk dokumen PO dalam EDI Format ANSI.

\begin{tabular}{|c|}
\hline ANSI EDI PURCHASE ORDER \\
\hline $\begin{array}{l}\text { ST*350*540001 } \\
\text { BEG*00*5A*4768*65*20120930 } \\
\text { N1*50*MZ Company } \\
\text { N3*123 Main Street } \\
\text { N4*Fainview*CA*94168 } \\
\text { P01*1*100*EA*27.65*"VN*331896-42 } \\
\text { CT*1*100 } \\
\text { SE*g*540001 }\end{array}$ \\
\hline
\end{tabular}

\section{Gambar 7. Purchase Order EDI Format ANSI}

Standar EDIFACT memungkinkan perusahaan lintas negara maupun lintas industri untuk saling bertukar dokumen bisnis elektronik (OpenText Business Network SA, 2015). Standar EDIFACT dipergunakan secara luas di negara-negara eropa. Standar EDIFACT untuk dokumen PO diperlihatkan dalam Gambar 8.

\section{EDIFACT EDI PURCHASE ORDER \\ UNH+SSDD1 +0RDERS:D:038:UN:EANO08 \\ $B G M+220 * 4768+9$ ' \\ DTM+137:20120930:102' \\ $\mathrm{NAD}+\mathrm{BY}+5412345000176: 94+\times \mathrm{XYZ}$ Company \\ +123 Main Street+Faiview+CA+94168+US' \\ LIN+1+1+331896-42:VN \\ QTY+1:100:EA \\ PRI+AAA:2765 \\ UNS+S' \\ CNT+2:100 \\ UNT+10+5SDD1}

\section{Gambar 8. Purchase Order EDI Format EDIFACT}

Apabila melihat kepada komponen sebuah dokumen PO konvensional dengan PO EDI, tidak terdapat perbedaan antara kedua jenis versi dokumen PO tersebut.

Elemen data dan bagian dari dokumen bisa dibandingkan pada Gambar 9, Gambar 10 dan Gambar 11.

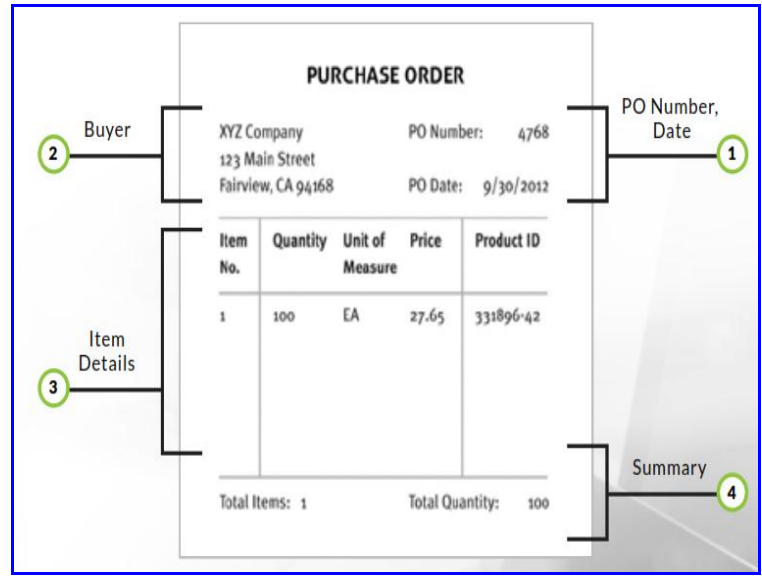

Gambar 9. Komponen Dokumen PO

Setiap komponen dari PO (angka 1-4) yang berisikan informasi berbeda-beda, pada EDI akan dibagi kedalam sejumlah EDI segment, yang ditandai 
oleh penanda seperti ST, BEG, N1 dalam kode ANSI atau UNH, BGM, DTM dalam kode EDIFACT.

\begin{tabular}{|c|c|}
\hline $\mathrm{ST}^{\star} 850 * 54001$ & $\begin{array}{l}\text { ST, to indicate start of a transaction set-in this case the } 850 \\
\text { purchase order }\end{array}$ \\
\hline $\mathrm{BEG} * 00^{*} \mathrm{SA}^{*} 4768^{*} 65^{\star} 20120930$ & $\mathrm{BEG}$, to indicate the beginning of the $\mathrm{PO}$, specifically (1) \\
\hline $\mathrm{N} 1^{\star} \mathrm{SO}{ }^{\star} \mathrm{XYZ}$ COMPANY & N1, a name segment (2) \\
\hline N3*123 MAIN STREET & N3, to provide street address \\
\hline N4*FAIRVIEW*CA*94168 & N4, to provide city/state/zip \\
\hline $\begin{array}{l}\mathrm{P} 01^{\star} 1^{\star} 100^{\star} \mathrm{EA}^{\star} 27.65^{\star \star} \\
\mathrm{VN}^{\star} 331896-42\end{array}$ & P01, to provide line item detail (3) \\
\hline $\mathrm{CTT}^{*} 1^{*} 100$ & CTT, to provide summary data for the PO (4) \\
\hline $\mathrm{SE}^{\star} 8 * 1001$ & SE, to indicate the end of the PO \\
\hline
\end{tabular}

Gambar 10. Dokumen PO dalam Format ANSI X12

\begin{tabular}{|c|c|}
\hline $\begin{array}{l}\text { UNH+SSDD1+ORDERS:D: } \\
\text { O3B:UN:EAN008' }\end{array}$ & $\begin{array}{l}\text { UNH, to indicate start of message } \\
\text { —in this case "ORDERS" }\end{array}$ \\
\hline $\mathrm{BGM}+220+4768+9^{\prime}$ & BGM, to indicate the beginning of the PO message \\
\hline DTM+137:20120930:102' & DTM, to indicate the date/time period (1) \\
\hline $\begin{array}{l}\text { NAD+BY+5412345000176::9 } \\
++ \text { +XYZ COMPANY+ } \\
123 \text { MAIN STREET+ } \\
\text { FAIRVIEW+CA+94168+US' }\end{array}$ & $\begin{array}{l}\text { NAD, to identify the buyer code corresponding to } \\
\text { the name/ address (2) }\end{array}$ \\
\hline $\mathrm{LIN}+1+1+331896-42: \mathrm{VN}^{\prime}$ & LIN, to describe line item detail ( 3 ) \\
\hline$Q T Y+1: 100: E A^{\prime}$ & QTY, to define the quantity \\
\hline PRI+AAA:2765' & $\mathrm{PRI}$, to define price \\
\hline UNS $+S^{\prime}$ & $\begin{array}{l}\text { UNS, section control segment to separate line item detail from } \\
\text { summary information }\end{array}$ \\
\hline CNT+2:100' & CNT, to provide the number of line items ( 4 ) \\
\hline UNT+10+SSDD1' & UNT, to indicate the end of the PO \\
\hline
\end{tabular}

\section{Gambar 11. Dokumen PO dalam Format EDIFACT}

Setelah seluruh segment disusun lengkap secara berurutan, maka akan terbentuk sebuah dokumen elektronik lengkap atau complete electronic document yang diistilahkan sebagai sebuah transaction set (OpenText Business Network SA, 2015). Transaction Set dalam Format ANSI X12 diperlihatkan dalam Gambar 12, sedangkan Transaction Set dalam Format EDIFACT diperlihatkan dalam Gambar 13.

Selanjutnya sebagaimana paket data pada umumnya yang akan ditransmisikan di jaringan, maka setiap paket data akan ditandai oleh sebuah envelope. Paket data yang dikirimkan di media jaringan, bisa saja akan menempuh jalur berbeda dan dalam urutan yang berbeda, sehingga envelope akan menandai sebuah paket data.

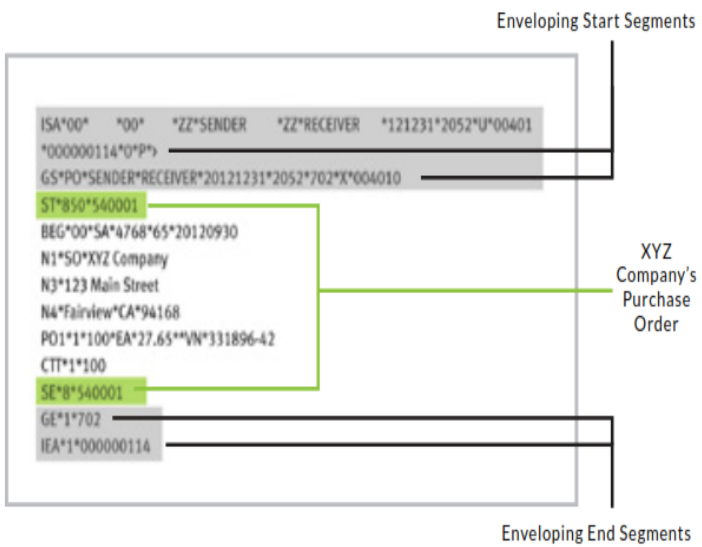

Gambar 12. Transaction Set dalam Format ANSI X12

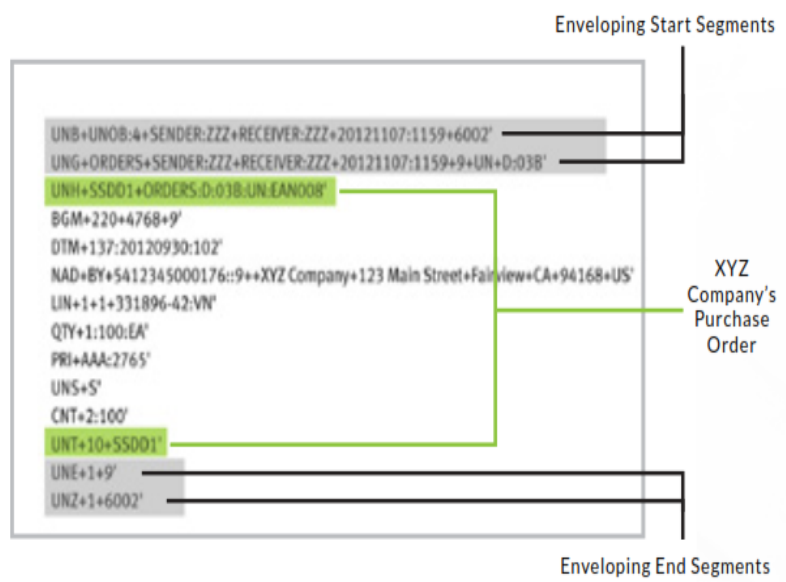

Gambar 13. Transaction Set dalam Format EDIFACT

\section{III.3 Dukungan Teknis}

Sistem EDI membutuhkan dukungan teknis yang memadai. Perusahaan maupun instansi yang telibat dalam kerja sama bisnis umumnya mempergunakan media jaringan yang berbeda, protokol yang beragam dan penyedia layanan yang berlainan.

Untuk menunjang reliability sistem EDI, perlu ditunjang oleh kinerja jaringan yang baik. Untuk itu diperlukan dukungan jaringan yang dikenal dengan istilah Value-Added Network (VAN).

VAN memungkinkan perusahaan untuk menggunakan jalur komunikasi data tunggal menuju penyedia layanan (termasuk penyedia layanan EDI/EDI service provider), yang kemudian menyediakan konektivitas menuju partner bisnis perusahaan tersebut (OpenText Business Network SA, 2015). 


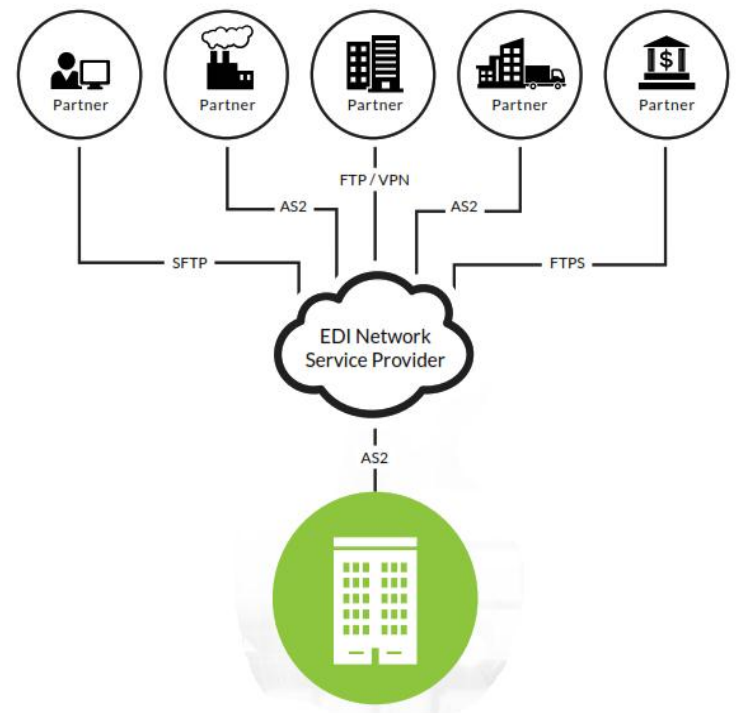

Gambar 14. Model Jaringan Penunjang EDI

Dengan konsep jaringan seperti yang diperlihatkan didalam Gambar 14, maka perusahaan dan partner bisnisnya akan memiliki kemandirian untuk membangun infrastruktur jaringan mereka masingmasing. Hal ini akan menjadi komponen penting efisiensi biaya dalam membangun sistem EDI. Yang perlu diperhatikan adalah masalah ketersedian sumber daya manusia di perusahaan yang harus terlatih menangani dokumen EDI, serta biaya (fee) transaksi yang harus dibayar kepada EDI service provider, dimana besar fee sesuai dengan jumlah transaksi yang terjadi melalui jaringan EDI (EDI network).

Oleh karena itu, seringkali pula dipergunakan kombinasi antara direct connection melalui jaringan internet dengan EDI network, dimana pemilihan jenis konektivitas disesuaikan dengan volume transaksi yang terjadi.

\section{KESIMPULAN DAN SARAN}

\section{IV.1 Kesimpulan}

Dari studi dan kajian dari penelitian ini, dapat disimpulkan hal-hal sebagai berikut:

1. Industri manufaktur merupakan representasi dari model $\mathrm{B} 2 \mathrm{~B}$ e-commerce yang hanya mampu berjalan efektif ketika konsep SCM bisa dijalankan sebagaimana mestinya

2. EDI merupakan model pertukaran informasi dan data secara elektronis yang sangat bermanfaat dalam pengelolaan jejaring B2B e-commerce, termasuk dalam jejaring bisnis industri manufaktur.
3. EDI mampu menjembatani sinkronisasi dan pelayanan real time antar relasi/rekanan bisnis dalam industri manufaktur, selama informasi atau data yang dipertukarkan bersifat rutin dan tidak membutuhkan human intervention dalam proses tersebut.

4. EDI belum mampu menjembatani pertukaran informasi yang membutuhkan pengambilan keputusan maupun analisa dari manusia (human).

5. EDI bermanfaat meningkatkan efisiensi waktu dan efektifitas kerja proses produksi secara keseluruhan, jika dijalankan secara konsisten dan terpadu (integrated) diantara relasi/rekanan bisnis.

\section{IV.2 Saran}

Untuk penelitian berikutnya dapat dilakukan serangkaian penelitian mengenai efektifitas sistem EDI dalam industri manufaktur, yang bisa ditinjau dari aspek kematangan teknologi dan keberhasilan penerapan sistem ini dalam industri manufaktur

\section{REFERENSI}

Albrecht, C. C., Dean, D. L., \& Hansen, J. V. (2003). Market Place and Technology Standards for B2B. ECommerce: Progress and Challenges. Seattle: A Critical Research Frontier for Information Systems, MISQ Special Issue Workshop.

Philip, A., Oluwatolani, O., \& Joshua, A. (2011). Development of a Window Based Security System for Electronic Data Interchange. Journal of Computer Science and Engineering Volume 7, Issue 2, 68-77.

Harland, C. M. (1996). Supply Chain Management: Relationship, Chains and Networks. British Journal of Management, S63-S80.

Council of Supply Chain Management Professionals. (2017, Oktober 21). CSCMP. Retrieved from CSCMP Supply Chain Management Definitions and Glossary: http://cscmp.org/CSCMP/Educate/SCM_Def initions_and_Glossary_of_Terms/CSCMP/E ducate/SCM_Definitions_and_Glossary_of_. Terms.aspx?hkey $=60879588-\mathrm{f} 65 \mathrm{f}-4 \mathrm{ab} 5-$ 8c4b-6878815ef921. 
RDP Crystal. (2015, Agustus 7). RDPCrystal Blog What is EDI. Retrieved from www.rdpcrystal.com/what-is-edi/.

Kokemuler, Neil. (2017, September 1). Chron - Small Business. Retrieved from http://smallbusiness.chron.com/purchaseorder-work-40933.html

OpenText Business Network SA. (2015, September 6). EDI Basics - Your Resources for Learning About EDI. Retrieved from edibasic: www.edibasics.com. 